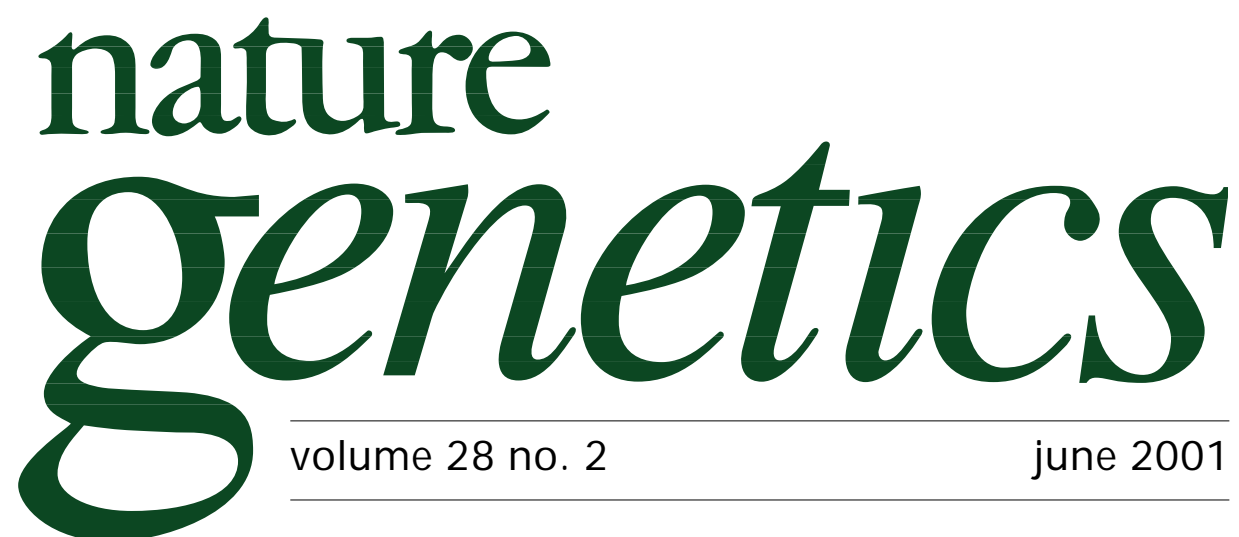

\title{
Stem cell decision time
}

The rapid march of modern biology doesn't give society much time to figure out a coherent response to its discoveries. Cultures of human embryonic stem cells were first created in the laboratory in 1998 (Science 282, 1145; 1998). In 1999 and 2000, the implications of the discovery were mulled, and interested parties began to mobilize opinion for and against further pursuit of the research. Now it is 2001 and, for research agencies and governments around the world, decision time has arrived.

Embryonic stem cells are pluripotent, or capable of developing into many different types of cells. They can differentiate into any type of tissue or organ, presenting the enticing prospect that they could one day be used to replace diseased or damaged cells and tissue. But questions about the genetic make-up of the cells and about the extent to which their apparently limitless potential can be harnessed remain manifold. These will only be addressed by more research on the cells, which can, of course, only be extracted from human embryos.

Given the moral implications of this extraction and the sanctity attached to embryos by many groups and individuals around the world, it is unsurprising that the question of how the research should proceed has spawned an energetic debate (see www.stemcellfunding.com for the case in favour, www.stemcellresearch.org for the arguments against). And although it can be difficult for researchers to recognize the fact, it is in the real interests of both science and society that research should pause for a short time while such a debate unfolds.

In this case, the pause has been punctuated by increasingly strident claims for the potential of adult stem cells to demonstrate at least some of the characteristics that make embryonic stem cells of such special interest. In the last few weeks, every finding concerning adult stem cells has been jumped upon by opponents of embryonic stem cell research as evidence that the latter is unnecessary.

Against this background, society as a whole is struggling to reach consensus on the rules that should guide the research. The struggle has been least pronounced in basically secular countries such as Britain, where a law was passed in January that will permit not only research on the stem cells themselves but also the creation of embryos expressly for research purposes by means of therapeutic cloning.

Elsewhere in Europe and in the United States, consensus on the issue is more elusive. Therapeutic cloning has been rejected as "premature" by an ethics panel advising the European Union, and is not likely to be permitted (at least using federal research dollars) in the United States.

In much of Europe, governments are gradually moving towards an arrangement that will allow only surplus embryos (left over from attempted fertility treatments) 
to be used for stem cell research. But political opposition to such an arrangement remains powerful.

Germany's situation brings out the basic character of the debate. Last month, after due consideration, the country's main research agency, the Deutsche Forschungsgemeinschaft (DFG), was all set to give a general go-ahead to embryonic stem cell research, and even to fund its first grant, to a neuroscientist at the University of Bonn. However the federal government, which is facing election next year, took the unprecedented step of declaring its disagreement with the DFG's decision, and seems to have encouraged the nominally-independent research agency to sit on its grant, at least for a few more months (see Nature 411, 119; 2001).

It is in the United States, however, that the debate continues to generate the most heat. It began auspiciously enough, at least from the scientists' point of view, under the Clinton administration. In a carefully-finessed legal ruling released early in 1999, the Department of Health and Human Services (which oversees the National Institutes of Health NIH) said that research on embryonic stem cells would be exempt from a US law banning the federal government from supporting embryo research-subject to a several conditions being met.

The ruling would have allowed the research to be supported, providing that the government wasn't paying for the derivation of the embryonic stem cells. Like most compromises, this one drew fire from all sides. It might appear unseemly for the government to support the research while saying that it would not support the dirty deed, as it were, of deriving the cells in question from human embryos.

However the health department ruling was supposed to deal with the world as it is, rather than we would like it to be. There is a large body of opinion in the country that will resist the government's involvement in the destruction of embryos. And there are scientists and, most importantly, patient advocates who will demand that the limits of human knowledge should be pressed in order to address the tragedy of disease.

So the compromise, which would have resulted in the NIH considering its first grant applicants for stem cell research in March of this year, was one with which North America - including many foes of abortion in Republican-controlled Congress - could have lived.

But as Nature Genetics went to press, the administration of George W. Bush was considering its position on this matter, and the portents for the survival of the compromise did not look good. Tommy Thompson, the health secretary and former governor of Wisconsin, has supported stem cell research earlier in his career and enthusiastically praised some of its pioneers, who did their work in his state.

However the abrupt cancellation, apparently on orders from above, of an April meeting at which the NIH would have considered its first embryonic stem cell grant applications, suggests that the administration is preparing to take a position that will bar human embryo research from receiving US public funds.

Such an outcome would be regrettable on a number of levels. Unlike in Europe, the decision taken by the US government is likely to reach only as far as publiclyfunded research. If it bars stem cell research, it will simply drive it into the private sector, where its outcomes will be heavily patented, minimizing their impact on science and on patient therapy.

By turning its back on stem cell research, in the face of considerable medical and scientific support for it, the administration may deter scientists of the top rank from accepting senior scientific positions - including the directorship of the NIH because of their reluctance to publicly support a policy with which they disagree.

And most importantly, by excluding the NIH, the largest biomedical research agency in the world, from joining in the scientific effort to learn more about embryonic stem cells, the Bush administration would diminish the otherwise bright prospects that their remarkable properties can be used in the treatment of disease.

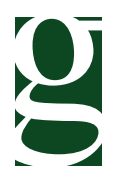

